SCJR 11, no. 1 (2016): 1-3

\title{
Sara Lipton \\ Dark Mirror: The Medieval Origins \\ of Anti-Jewish Iconography
}

(New York: Metropolitan, 2014), xxi + 390 pp.

\author{
EVA FROJMOVIC \\ e.frojmovic@leeds.ac.uk \\ The University of Leeds, Leeds, LS2 9JT, UK
}

This book, long awaited since the author's magisterial Images of Intolerance of 1999, is a masterful cultural history, one that moves well beyond simple reductions of imagery to "historical background." It arises from a need to transcend deterministic histories that see images as transparent "reflections" of a predetermined, often not sufficiently critically interrogated history (p. 9). The author refuses a simple teleology from early medieval (relative) Christian tolerance of Jews to a late medieval anti-Judaism and then finally to modern anti-Semitism. The book is not so much about iconography but about epistemology (that is, the history of knowledge and of ideas about knowledge). The book asks less what images mean than "what work [they] do for the culture that created them" (p. 6). In a series of closely argued case studies arranged in chronological order, it traces how significant changes in western medieval visual culture, and the incredibly contested cultural role of vision, led to multiple repositionings of the wrong (i.e., rejected, condemned) kind of vision as "Jewish." The quote marks are deliberate: the author shows that the visual polemics in which figures marked as Jewish appear are internal Christian debates in which real-life Jews, or policies toward Jewish individuals and communities, play a secondary role. The relationship between visual images and history is never simple.

The book starts with a startling assertion: "for the first thousand years of the Christian era, there were no visible Jews in Western art" (p. 1). Actually, Lipton notes, biblical figures appear abundantly in medieval western artworks, as one would expect from a culture so closely identified with the sacred scriptures. But because Christian theology was focused on the idea that Christianity was the successor of and had displaced Judaism, it was inconceivable that Judaism should continue to evolve. Therefore Jews in medieval time were seen as entirely separate from biblical Israelites. It is only in the twelfth century that contemporary Jews appear for the first time, as witnesses to new, miraculous events such as the birth of new saints. These contemporary Jews do not reflect anti-Judaism. Rather, they are valued as independent witnesses to Christian truths whose credibility results precisely from their outsider status. 
The book is as much about seeing as it is about visual signs. And seeing (i.e., vision) was perceived with ambivalence: "Christian epistemology would reverberate with this tension between deprecation of reliance on physical vision as inconsonant with faith and longing for direct, visual experience of the divine" (p. 6). Lipton argues that in the early Middle Ages, "The augmented religious role afforded visual experience in high medieval Christianity largely explains the new visual prominence of the Jew. As the paradigmatic exemplar of the physical vision and its misuse, the figure of the Jew became the primary medium through which Christians explored and expressed their changing ideas about knowledge, vision, and re-presentation" (pp. 6-7).

The book is arranged in seven chronological chapters from approximately the year 1015 to 1500 . There is one exception: chapter six is devoted to the question of gender, and the observation made by the author that most of the representations of biblical Israelites and contemporary Jews were men.

The first three chapters cover the period from 1015 to 1220 . The fourth and fifth chapters cover the remainder of the thirteenth century and up to the middle of the fourteenth century. The sixth chapter, as already mentioned, deals with the relative absence of Jewish women in medieval iconography. The final chapter covers the period from 1350 to 1500 . As can be seen, the pace of the book accelerates with each chapter. And it is clear that the research is most focused on the eleventh- and twelfth-century origins of long-lived signs such as the beard and the so-called Jewish hat.

In chapter one, Lipton traces the images of the so-called Jewish hat back as far as Bishop Bernward's second gospel book (ca. 1015). In this manuscript, pointed hats were worn primarily by the three magi. In them, the patron "saw not his Jewish subject and neighbors but himself. Because the pointed hat signals not Jewishness but knowledge and authority, it functions not to distinguish Jews from Christians but to link the medieval Christian Bishop to his ancient forerunners, gentile and Judean" (p. 39). Through an investigation of the appearance of such hats, Lipton argues that "living medieval Jews were not the main inspiration" for images. Also, "the 'Jewish hat' was not inescapably negative" (p. 44-45). Similar to the hat, beards were unstable signifiers. As norms and fashions for facial hair changed, and as the biblical past, no longer in a line of continuity, receded in time, the beard acquired some "fairly exotic connotations: an aura of worldliness, the whiff of the updated past, or a hint of Muslim or Greek 'Easternness"' (p. 50).

The second chapter makes quite a sensational contribution: Lipton has identified one of the earliest artistic occurrences of a contemporary Jewish figure. He appears first in a Christian text and then in a reliquary based on the text. Perhaps unsurprisingly, this figure occurs in the writings of Rupert of Deutz, the early twelfth-century theologian who wrote so fascinatingly about the roles of art in religion and about Jewish-Christian debate. Lipton found that Rupert rewrote the life of a sainted Archbishop of Cologne and invented a Jewish friend for the Archbishop's father. When a golden reliquary shrine was sculpted for this Archbishop after his death and canonization, this Jewish friend acquired a name (Aaron the Jew) and an image as a dignified figure wearing a pointed hat. The 
novelty of this figure is that he is neither biblical nor apocryphal, but lived in the present. This Jewish friend witnessed the birth of the hero. In a context in which sainthood could be conferred only upon the testimony of witnesses, Augustine's idea of Jewish witness, a purely theological concept, was translated into the present.

A central theme that Lipton has investigated for some time is the controversial role of art in an era of church reform. Paradoxically, both reformers and their opponents identified themselves with the ancient Hebrews, while denigrating each other and each other's art as "Jewish." Therefore, there is no stable Jewish iconography, but only shifting signifiers. Chapter three is devoted to the problem of the new Christian affective piety of the twelfth and thirteenth centuries, which depicted Jesus in an increasingly naturalistic, "ugly" way. This posed a problem for the users of images. To teach "correct" devotional viewing, those who found ugly images abhorrent were accused of "Jewish" literalism. The polemic, however, was an entirely internal Christian one. This undermines explanations of these images as defined by anti-Judaism.

The work that stands at the center of chapter four is the cathedral at Chartres, a "great multimedia monument" (p. 133). Lipton sees the cathedral as a mirror of Christian society. She concludes that despite the well-known anti-Jewish elements in the developing cult of the Virgin Mary of which Chartres was a center, there is no single meaning to figures marked as Jewish. She writes, "to see the images of Jews at Chartres as powerfully anti-Jewish requires very selective reading indeed, or wilful disregard of the visual similarity between Jewish moneylender and generously forgiving father" (p. 167).

The contribution of this book is as much methodological as it is historical. We learn much about method-how to link images, texts, and historical context - and about all the different things that historical context might be to scholars from different disciplines. Lipton is adamant that art does not simply reflect a seemingly pre-existing history. She is very aware that, in her own words, "art can affect as well as reflect the culture that creates and views it" (p. 41). In other words, art contributes to the construction of mentalities; it does not just reflect them. In this case, the whole book is devoted to undoing an established history of iconography situating art in a framework of anti-Semitism and anti-Judaism. While seemingly similar in scope to previous books like H. Schreckenberg's The Jews in Christian Art: An Illustrated History (1996), it in fact argues against retrospectively constructing a linear history of anti-Judaism from the visual arts. 